\title{
Agricolan Rukouskirjan yhtyys
}

\section{Johdanto}

Yksi-numeraalilla on ollut vanhassa kirjasuomessa viisi erilaista ominaisuudennimijohdosta. Näistä yleisin on yhteys, joka esiintyy sekä Agricolan teoksissa että vanhimmissa käsikirja- ja messuteksteissä (Westhin koodeksi, Upsalan koodeksi ${ }^{1}$ ). Yhteyden lisäksi on joskus käytetty pitkävokaalista asua yhtyys : yhtyyde- tai sen lyhytvokaalista vastinetta yhdys : yhtye-. Neljäntenä varianttina on eräissä 1500- ja 1600-luvun teksteissä esiintyvä $y k s y y s$, mutta sitä on käytetty vain yhdyssanassa kolm(i)yksyys 'kolmiyhteys'. 1700-luvulla on tullut vielä yksi johdos, ykseys. Varianteista yhtyys : yhtyyde- ja yhdys : yhtye- ovat peräisin murteista. Ominaisuudennimien alkuperäinen johdin on ollut lyhytvokaalinen -us, -ys : -ute-, -yte-, ja vanhan kirjasuomen yhdys : yhtye- edustaa tätä kantaa. Erilaiset analogiat ovat muovanneet johdosta ja sen taivutusta muun muassa niin, että konsonantin jälkeiseen asemaan on vakiintunut pitkävokaalinen johdin ( $y$ htyys). ${ }^{2}$ Vaikka jälkitavujen pitkät vokaalit on vanhassa kirjasuomessa merkitty yleensä yhdellä kirjaimella, ominaisuudennimissä on Agricolasta lähtien kaksikirjaimistakin merkintätapaa (coctuus, autuutta; Rapola 1965, 73; Kiuru 1988, 161). Pitkän vokaalin merkintä vaihtelee myös

1 Molemmat koodeksit sisältävät käsikirjan ja messun. Tekstit on ajoitettu 1540-luvulle, mutta niissä on ilmeisesti vanhempaakin ainesta. (Pirinen 1988, 17, 21, 23.)

2 Kaksitavuisten kantasanojen ominaisuudennimijohdokset ovat olleet alun perin tyyppiä vanhus(i) : vanhuen > vanhuun : vanhuena : vanhutta : vanhusia. Tästä tyypistä on vanhan kirjasuomen lisäksi jäänteitä myös joissakin murteissa. Lyhytvokaalisesta johtimesta Ute on kehittynyt nominatiivissa äänteenmuutosten myötä $U s(-e>-i, t i>s i$, i:n loppuheitto). Muissa muodoissa $t$-aines on mukautunut suffiksaaliin astevaihteluun, niin että painottoman tavun jäljessä se on heikentynyt ja kadonnut ( $\left.{ }^{*} v a n h u \delta e->v a n h u e-\right)$, painollisen tavun jäljessä säilynyt ja mukautunut radikaaliin astevaihteluun (ahkerus : ahkeruden : ahkerutena). Nykymuotojen pitkä vokaali, $t: n$ radikaali astevaihtelu ja monikon kse-vartaloisuus ovat syntyneet erilaisten analogioiden tuloksena: vanhuus : vanhuuden : vanhuutena : vanhuuksia. (Rapola 1966, 154-158; Hakulinen 1979, 144-145.) 
johdosvarianteissa $y$ htyys ja $y k s y y s .^{3}$

Valtavariantiksi on kirjasuomeen ja nykykieleen vakiintunut vanhimmista kirjallisista teksteistä lähtien yhteys. Sen kansanomaista alkuperää on vaikea jäljittää tai osoittaa, ja se saattaa olla tietoinen uudismuodoste, joka on luotu ilmaisemaan kirkollisen kielen ja lakikielen käsitteitä. Vaikka vokaaliyhtymäinen yhteys kuuluu myös murteisiin, se ei Suomen murteiden sana-arkiston mukaan ole niissä niin yleinen kuin yhtyys (SMSA). Yhteyden levikki näyttää arkistoaineiston perusteella painottuvan enemmän länsimurteisiin, mutta se voi silti olla näissäkin kirjallista alkuperää. ${ }^{4}$ Myöhemmin käyttöön otetut variantit $y k s e y s$ ja $y k s y y s$ ovat joka tapauksessa $y k s i$-kannasta muodostettuja uudissanoja, jotka rinnastuvat vokaalistoltaan johdospariin yhteys ja yhtyys. Niiden rakenne poikkeaa yhte-morfeemin alkuperäisestä äännevaihtelusta, johon on päädytty äänteenmuutosten $k t(e)>h t(e)$ ja $t i>$ si kautta: ykte > yhte, ykti > yksi (Hakulinen 1979, 41, 53). Yksey-

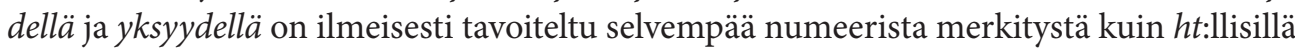
varianteilla on ollut. Yksi-kantaisen sanaston karttuessa on konsonanttiaineksen vaihteluissa tapahtunut yleisemminkin siirtymä semanttisehtoiseen vaihteluun, niin että $h t: 11$ nen allomorfi viittaa yhteenkuuluvuuteen, $k s$ :llinen numeerisuuteen (Koski 1979, 20).

Seuraavassa tarkastelen Agricolan käyttämää yhtyys-johdosta. Variantti esiintyy hänen teoksissaan vain kerran, ja sen käyttö eroaa muista vanhan kirjasuomen tapauksista. Taustaksi luon ensin katsauksen eri johdostyyppien vaihteluun vanhimmassa kirjasuomessa. Olen aiemmin käsitellyt 'ykseyden' ja 'kolmeuden' ilmaisemista kolminaisuusopillisessa sanastossa (Mielikäinen 2017). Agricolalla on ollut näistä Jumalan persooniin ja jumaluuteen viittaavista käsitteistä runsas sanavalikoima, johon kuuluu sekä johdoksia että yhdyssanoja, esimerkiksi 'ykseydestä yhteys, yksinäisyys ja $y k s i(n) k e r t a i s u u s ~(m t .$, 38-39). Yhtyys jää käyttötapansa vuoksi kuitenkin mainitun aihepiirin ulkopuolelle.

\section{Johdostyyppien vaihtelu vanhimmassa kirjasuomessa}

Eri variantit eivät ole vanhassa kirjasuomessa olleet täysin synonyymisia, vaan niillä on jossain määrin pyritty erottelemaan käsitteitä, merkityksiä ja konteksteja. Yhteys on varianteista monikäyttöisin, ja siitä on jo varhain tullut teologisen ja lainopillisen kielen termi. Abstraktien käsitteiden lisäksi sitä on käytetty konkreettisemmissakin merkityksissä,

3 Kirjoitusasusta riippumatta variantit yhtyys : yhtyyt- ja yhdys : yhdyt- ovat erotettavissa toisistaan kantavartalon astevaihtelun perusteella $(h t: h d)$.

4 Ominaisuudennimijohdin on ollut koko kirjasuomen historian ajan yksi produktiivisimpia johtimia, ja Agricolan teksteissä on runsaasti sillä muodostettuja abstrakteja uudissanoja. Murteiden ominaisuudennimet ovat olleet alkuaan lähinnä adjektiivikantaisia, konkreettisia sanoja, joilla on ilmaistu muun muassa ikää, kokoa, määrää ja mittaa. Niissä on vähän $e$-kantaisia johdoksia (esim. pienuus, suuruus). Vaikka kantasanan vartalovokaali on kadonnut pitkävokaalisen johtimen edeltä ( $y$ hte- $>y h$ tyys), kirjasuomeen on jäänyt joistakin vartalotyypeistä vokaaliyhtymäinen variantti ( $y$ hteys, heikkous, murt. myös heikkuus). Myöhemmät $e$-kantaiset tapaukset ovat yleensä vokaaliyhtymäisiä: tyyneys, täyteys, veljeys (vanha kirjasuomi leskeys leskiys, murt. myös leskyys). (Ks. Rapola 1965, 309.) 
kuten 'ykseys, kosketus, osallisuus' tai 'seurakunta, yhdistys, yhtiö. Pelkästään teologiseen kieleen luotuja johdoksia ovat (kolmi)yksyys ja ykseys. Kolmiyksyyden on myöhemmin korvannut käännöslaina kolmiyhteys (ensiesiintymä 1701), ja ykseys (ensiesiintymä 1758) on puolestaan syrjäyttänyt vähitellen yhteyden numeerisessa tai yhtenäistä kokonaisuutta tarkoittavassa merkityksessä (Jussila 1998 s.v. kolmiyhteys; Mielikäinen 2017, 30-31, 35-38). Murteiden äänneasua yhtyys on käytetty ei-teologisissa konteksteissa, yleisimmin fraasissa pitää yhtyyttä, josta on esimerkkejä vielä 1700-luvun lakikielessä (VKK). Pitää yhtyyttä 'olla tekemisissä, yhteydessä, sukupuoliyhteydessä' on murteissakin yksi sanan yleisimpiä käyttökonteksteja.

Vanhan kirjasuomen sanastolle on tyypillistä se, etteivät merkitysten rajat ole olleet tarkat. Paitsi että samaa sanaa on voitu käyttää polyseemisesti eri merkityksissä, kuten yhteyttä, myös yhtä käsitettä on ilmaistu useammalla lekseemillä. Havainnollinen esimerkki johdosten synonymiasta ja sananvalinnan ongelmista on 'talousyhtiön' käsite vanhimmissa lakiteksteissä, sillä sitä on ilmaistu useilla erilaisilla $y k s i$-kantaan palautuvilla nominijohdoksilla: yhteys, yhtyys, yhdys; (verbikantaisia) yhdistös, yhdytys yhdytös. Ljungo Tuomaanpojan (1601) ja Abraham Kollaniuksen (1648) termistöä ovat (talon) yhteys, yhtyys ja yhdistös, kun taas yhdys ja yhdytys yhdytös esiintyvät vain vanhimmassa tekstissä, Martin maanlain suomennoksessa (1580-luvulta): Taloin yhdys iongun cansa (Martti-170) taloin yhteyxest eli yhdhytyxest (Martti-54) talon yhtydhen penningit (Martti-139). (VKK; LTS s.v. talonyhteys 'bolag'.) Verbikantaisista johdoksista yhdistys on säilynyt koko vanhan kirjasuomen ajan yhteyden synonyymina (Jussila 1998 s.v. yhdistys; Mielikäinen 2017, 29-30).

Kirkollisessa kielessä $y k s i$-kantaisilla ominaisuudennimillä on ollut siinä määrin eriytyneitä käyttökonteksteja, että johdostyyppejä pystyy vertailemaan eri käännösversioista tai samoista tai samojen kirjoittajien teksteistä. Yhtyyden erottaminen yhteydestä käy ilmi muun muassa vuoden 1642 Bibliasta, jossa on aina yhteys lukuun ottamatta pari kertaa esiintyvää ilmausta pitää yhtyyttä (porttojen kanssa) ${ }^{5}$. Myös Finno on käyttänyt tätä fraasia virsikirjansa esipuheessa puhuessaan yhteisymmärryksestä "opissa, saarnoissa ja veisuissa"; sen lisäksi hänellä on virsiotsikkona yhdyssana kolmyksyys (Finno 1583, 12, 114). Hemmingin virsiteksteissä esiintyvät puolestaan yhteys ja kolmyksyys (1601, 1616; VKK). Tarkimmin on johdostyypit erotellut kirkollisessa kielessä Paavali Juusten. Hänen Messussaan 1575 on $y k s i$-kantaisista ominaisuudennimistä kolme erilaista varianttia: $y h t e y s$, yhtyys ja (yhdys:) yhtye-. Tapaukset kuuluvat keskeisiin käsikirjan ja Raamatun teksteihin, ja ne poikkeavat osittain muista aiempien lähteiden vastineista, kuten seuraavista sitaateista käy ilmi:

5 Pitää yhtyyttä ja pitää yhteyttä esiintyvät vanhassa kirjasuomessa synonyymisesti rinnan, mutta jonkinlaisen merkityseron voisi nähdä seuraavissa Biblian 1642 esimerkeissä: Siir. 19:2 ne jotca porttoin cansa yhtyttä pitäwät; 1. Tim. 6:3 reunaselitys ettei hän yhteyttä pidäis heidän [väärien opettajien] cansans. Murteissa fraasilla on sekä sukupuolisen kanssakäymisen että muun yhteydenpidon merkitykset; vanhoissa lakiteksteissä pitää yhtyyttä viittaa useimmiten sukupuoliyhteyteen. 
(1a) Sinun Poias Jesuxen Christuxen meiden HERran cautta / ioca sinun cansas pyhän Hengen ychteydhes [lat. unitas] eläpi ia hallitzepi ijancaickisesta ijancaickisehen (rukouksen loppu, s. 38); vrt. ioca ynne ['yhdessä'] sinun cansas elepi / ja hallitzepi / saman pyhen hengen ychteyxes ijancaikisesta / ijancaikisehen (Agr. 1544, MAT I, 688); ioca sinun cansas elä ja hallitze Pyhän Hengen ychteyxes (Westh-171, VKK).

(1b) Ja achkeroicat pitämyn Hengesse ychteyttä [kreik. henotes] (Ef. 4:3, s. 128).

(2) Minä vscon - - pyhäin inhimisten ychtydhen [lat. communio] (apostolinen uskontunnustus, s. 12); vrt. Mine wscon - - Pyhein osanottamisen (Agr. 1549a, MAT III, 88); Vscokos - - pyhein osanottamisen (UpsKk-75, VKK); Pyhän osanottamisen (Westh-19, VKK).

(3) että me tunnusta taidham sinun oleuan personis polesta / totisen colminaisudhen ia cuitengin Jumalisesa olemisesa ydhen oik[i]an ychtyen [lat. unitas] (kolminaisuudenpäivän rukous, s. 100); vrt. Ja ette me / sinun yxikerdhasudhes ylenpaltista woijmas cwmardhaijsim (Agr. 1544, MAT I, 414).

Yhteyden valta-asemaa on vanhimmassa kirkollisessa kielessä vakiinnuttanut se, että sana on valittu latinan 'ykseyttä' tarkoittavan unitas-sanan vastineeksi jumalanpalvelusten kollehtarukouksissa toistuvaan loppudoksologiaan ${ }^{6}$ (esimerkki 1a). Agricola on taivuttanut johdoksen useimmiten Westhin tekstin tapaan kse-vartaloisena. Juusten on säilyttänyt sanan kyseisessä kontekstissa mutta korjannut kse-vartaloisen inessiivimuodon $y d e$-vartaloiseksi. Sen sijaan kolminaisuudenpäivän rukoustekstissä (esimerkki 3) hän on käyttänyt samassa merkityksessä varianttia ( $y h d y s:)$ yhtye- ${ }^{7}$. Rukous poikkeaa jonkin verran Agricolan Missale Aboenseen perustuvasta versiosta (Gummerus 1955, 196), ja Juustenin on todettu tässä kuten kollehtarukouksissa yleensä seuranneen enemmän ruotsalaisen evankeliumikirjan sanamuotoja (Parvio 1978, 78, 80, 124, 129). Apostoliseen uskontunnustukseen (esimerkki 2) Juusten on valinnut yhtyyden, kun Upsalan koodeksin (UpsKk), Westhin koodeksin ja Agricolan versioissa latinan communiota vastaa osanottamus : osanottamisen (VKK; mUs- ja minen-johdosten suhteista ks. Kiuru 1988, 172-177). Raamatuntekstin ilmaus pitää Hengessä yhteyttä (kreik. henotes 'yhteys, ykseys', esimerkki 1b) on jo

6 Kollehtarukous on vanha liturginen jumalanpalvelusrukouksen tyyppi. Se noudattaa tiettyä kaavaa, ja sen päättää ns. loppudoksologia eli Pyhälle Kolminaisuudelle osoitettu ylistys. (Gummerus 1955, 94; ks. myös Mielikäinen 2017, 28-29.)

7 Johdosvariantista $y h d y s$ : $y h t y e-$ on läpikäymässäni aineistossa vain kaksi esimerkkiä: Juustenin käyttämä taivutusmuoto $y$ htyen ja Martin maanlaissa esiintyvä nominatiivi (taloin) yhdys. Suomen murteiden sana-arkistossa on kaakkoishämäläisistä murteista esimerkki yhless yhtyves 'yhdessä' (Jaala, SMSA). Juusten on käyttänyt Messussaan kuitenkin useista muista ominaisuudennimistä heikkoasteisia rinnakkaismuotoja: neuhryella, hywyes, anal. awtuen, laupiuns hywydhes ja laupiudhes. Lyhytvokaalisen tyypin taivutusmuodot ja niihin perustuvat analogiamuodosteet ovat 1500-1600-luvun kirjasuomessa vielä melko yleisiä: pyhyesä, suuruens assimil. hyvyyns, nöyryyllä, anal. puhtaun, ahneun (Rapola 1965, 167-168; 1966, 158-159). 
Agricolan käännöksessä samassa muodossa (MAT II, 538), mutta siinä ei ole kyse kiinteästä fraasista pitää yhteyttä yhtyyttä. Esimerkit osoittavat Juustenin tunteneen erilaisia ominaisuudennimivariantteja ja tehneen tietoisia valintoja niiden teologisessa käytössä. Tämä selittää myös yhtyys-variantin poikkeuksellisen käytön uudessa kontekstissa. On huomattava sekin, ettei Juustenilla ole ollut vielä kovin monia tekstejä sananvalintojensa malliksi.

\section{Rukouskirjan yhtyys ja sen tulkinta}

Yhteys esiintyy Agricolan teoksissa yli 60 kertaa (IA), ja ainoa rinnakkaisvariantti on vain kerran esiintyvä yhtyys. Yhteys taipuu usein kse-vartaloisena, eivätkä tällaiset ominaisuudennimien taivutusmuodot ole harvinaisia muillakaan 1500-1600-luvun kirjoittajilla (Rapola 1965, 169). Yhteyden käytössä on useimmiten kyse kolminaisuusopillisesta 'Jumalan ykseyden' käsitteestä, ja sen frekvenssiä nostaa edellä mainittu rukousten loppuformula Pyhän Hengen yhteyksessä (esimerkki 1a). Lisäksi Agricola on käyttänyt yhteyttä muutaman kerran muissa merkityksissä, esimerkiksi Joel 2:16 Pyhitteket ne Ychteyxet (Agr. 1551a, MAT III, 636; Biblia 1642 yhteydet; Biblia 1776/1991 kokous); Ps. 86:11 reunaselitys Jumalan Sana / se pysy ia ychteyte tekepi (Agr. 1551b, MAT III, 337).

Johdostyypin yhtyys ainoa esiintymä kuuluu Agricolan Rukouskirjan rukouksiin, ja senkin taivutusmuoto on $k s e$-vartaloinen. Merkityksensä ja lauseasemansa puolesta sana on hankalasti tulkittava. Sitä ei voi rinnastaa käytöltään yhteyteen mutta ei myöskään muihin vanhan kirjasuomen yhtyys-tapauksiin.

(4) ette me madhaijsima sinun teruelisen Sanas / otolisesta licutta ['käsitellä] / ja luijasti wscoo / iosta me - - / iosta mös meiden omatundo totisesta ia teudhelisest iloijsaxi tulis / ia caikinaijsesta hengelisesta remusta teutetyxi tulis / nijn swresta ychtyxesta hywydhesta / cochta mös meiden keskellem / anna wahwa rauha / souindo / ia yximielisus caswa ja liseyte (Agr. 1544, MAT I, 622-623).

Ilmauksessa nijn swresta ychtyxesta hywydhesta on kaksi ominaisuudennimeä peräkkäin ja näiden edellä selvä adjektiiviattribuutti ${ }^{8}$. Elatiivimuoto näyttää jatkavan aiempien määritteiden luetteloa, mutta lausekkeen suhde predikaatteihin on epäselvä (tulis, täytetyksi tulis, anna). Sisällöllisesti ilmaus viittaisi luontevimmin aiemmin mainittuun sanaan. Lauseiden suhteita suurempi syntaktinen ongelma on peräkkäisten ominaisuudennimien keskinäinen suhde. Se ei voi olla rinnasteinen, 'yhteys ja hyvyys', sillä vanhalle kirjasuomelle tyypilliset paratagmat sisältävät yleensä sidesanan, myös sellaisissa tapauksissa joissa kansankieli on suosinut asyndeettista rinnastusta: Agr. yötä ja päivää, murt. yötä päivää. Merkitykseltäänkään yhtyys ja hyvyys eivät rinnastu toisiinsa samalla tavalla

8 Isossa suomen kieliopissa ei käytetä perinteisen kieliopin mukaista attribuutti-termiä. Sen asemesta puhutaan vain substantiivin (etu)määritteestä, sillä kyseessä ei ole lauseen vaan substantiivilausekkeen jäsen (VISK \$ 867). 
kuin paratagmojen osat yleensä. Ne eivät ole keskenään synonyymisia, tautologisia, toisiaan täydentäviä tai vastakohtaisia kuten esimerkiksi ilmauksissa armo ja laupeus, oikeus ja kohtuus, köyhä ja vaivainen, elävät ja kuolleet. (Rapola 1962, 176; Pulkkinen 1966, 159160; Nummila-Ojutkangas 2013, 73-76.) Agricolan teksteissä on runsaasti tautologisia paratagmoja, ja hän on käännöksiinsäkin lisännyt usein alkutekstin käsitteitä selittäviä synonyymeja (Holma 2008, 10, 179-182). Hyvyys-sanasta Agricolan teksteissä on sellaisia paratagmoja kuin hyvyys ja armo, hyvyys ja rakkaus sekä laupeus ja hyvyys.

Rinnasteisuuden sijaan peräkkäisten ominaisuudennimien jäsennykseen sopii paremmin alistussuhde, niin että yhtyys määrittää hyvyyttä. Näin tulkittuna yhtyys on siis adjektiivisessa käytössä, ja sen merkitykseksi sopisi 'yhteinen.9 Adjektiivi yhteinen (: -ise-itse-) on vanhassa kirjasuomessa erittäin yleinen, ja sillä on 1800-luvulle saakka ollut myös merkitys 'yleinen, tavallinen' (Ganander 1787 'allmän, gemensam'). Aina eivät merkitykset erotu selvästi toisistaan. Yhteinen esiintyy Agricolan teoksissa yli 80 kertaa (IA), ja se määrittää erilaisia asioita: yhteinen seurakunta, kansa, jumalanpalvelus, usko, rukous, rauha, rakkaus. Myös hyvyys voi saada määritteekseen yhteisen:

(5) O HERRA / anna meille sinun päälles wahwa wsco - - ette me neinnen auwoin cautta / mahdaijsima sinun edheses toiuo - - ia wissiste saadha / caikinaijset Rumijn ia Sijelun tarpet / erinomaiset ['omat, yksityiset'] ia ychteitzet hywydhet (Agr. 1544, MAT I, 106).

(6) Jumalasta) Ette Jumala meiden oma ombi / ia me olema henen Omansa / ia Hywuydhet ouat meile ychteitzet heneste (Room. 5:11 jälkiselitys, Agr. 1548, MAT II, 430).

Esimerkkien 4, 5 ja 6 rukouskatkelmat ovat sisällöltään samankaltaisia, ja siten myös yhtyyden voi olettaa esimerkissä 4 hyvyyden attribuutiksi. Hyvyys on murteissa leksikaalistunut tarkoittamaan muun muassa omaisuutta ja tavaraa, anteliaisuutta ja lempeyttä tai hyötyä ja etua (SMS s.v. hyvyys). Vanhassa kirjasuomessa johdoksen merkitykset ovat suunnilleen samat, joskin kuvallinen käyttö painottuu teologisissa teksteissä ja omaisuuteen sanalla viitataan erityisesti lainasuomennoksissa (VKS s.v. hyvyys). Merkityksen mukaan hyvyys voi olla joko yksikössä tai monikossa. Agricolan teksteissä hyvyys saa monikossa määritteekseen sellaisia abstraktisanoja kuin ajalliset, hengelliset, ihmeelliset, taivaalliset ja tulevaiset (hyvyydet). ${ }^{10}$ Esimerkeissä 4-6 on kontekstien perusteella kyse Jumalan antimiin ja lahjoihin perustuvasta käsitteestä, yhteisesti saadusta "omaisuudesta" (vrt. VKS s.v. hyvyys mm. 'lahja, antimet').

Yhtyydellä on murteissa merkityksiä ja käyttötapoja, jotka vahvistavat yhteisen, yhteisöllisen merkitystä. Yhteistoiminnasta on käytetty muun muassa ilmausta yhtyydessä.

9 Gummeruksen $(1955,401-402)$ tutkimuksessa Agricolan Rukouskirjan lähteistä ei ole kyseiselle rukoukselle vastinetta, joten sitä ei voi verrata alkutekstiin.

10 Lähellä yhteistä hyvyyttä on ilmaus yhteinen hyvä, joka on säilynyt fraasiutuneena vanhasta kirjasuomesta nykykieleen saakka, esim. palvella yhteistä hyvää 'etua' (NS s.v. hyvä, ks. myös yhteinen); vrt. Agr. Ja se on ychteinen hyue / ette sencaltaiset rangaistan (Agr. 1549b, MAT III, 53). 
Jotain on voitu hankkia yhtyydessä eli 'yhdessä, yhteisesti, yhteiseksi': Heinjoki Ostetaa se puimakone yhtyyves. Kaski on hakattu yhtyydessä eli 'yhdessä, kaskiyhtiössä', ja nuotanvedossa on menty yhtyyksille, kun on soudettu veneet yhteen. (SMSA.) Yhtyys on siis sopinut $y k s i$-kantaisista ominaisuudennimivarianteista parhaiten 'yhteisen' merkitykseen.

\section{Ominaisuudennimien adjektiivinen käyttö}

Agricolan yhtyys ei ole irrallinen esimerkki ominaisuudennimen adjektiivisesta käytöstä, sillä murteissa ja laajemminkin itämerensuomalaisissa kielissä näitä johdoksia on käytetty genetiivimääritteen kanssa mitan ilmauksissa: polven korkeus korkuus 'korkuinen', peukalon pituus 'pituinen' (ks. esim. SMS s.v. korkeus). Nykykielessä niiden sijasta käytetään kuitenkin ominaisuudennimistä johdettuja (u)inen, $(y)$ inen -adjektiiveja, kuten korkuinen (< korkuus), pituinen, levyinen; näillä ekvatiivijohdoksilla on vastineet myös virossa ja lapissa. (Hakulinen 1979, 144, 186-187.) Kirjasuomeen ekvatiiviadjektiivit on omaksuttu vasta 1700-luvulla: pituinen 1709, korkuinen 1782, levyinen 1783 , paksuinen, suuruinen ja syvyinen 1787 (Jussila 1998). 1500- ja 1600-luvun teksteissä mittaa on ilmaistu erityyppisillä ominaisuudennimen tai perusadjektiivin sisältävillä rakenteilla, ja tyyppi polven korkeus on voinut esiintyä adjektiivin tapaan attribuuttina (esimerkki 7 ) ja predikatiivina (esimerkit 8-10).

(7) Se on toimi aita että mös yxi cohtudest corkea mies vlottu ylitzen aidhan laskea toiselle puolelle mahan kynären pitudhella kadhikalla ['pituisella kalikalla'] eli satutta (Martti-66, VKK); vrt. kynärän pituella kaidickalla (Ljungo, Lju1601-56, VKK).

(8) Catzo / minun peiuni ouat kämmenen leueys sinun tykenes (Ps. 39:6, Agr. 1551b, MAT III, 266; samoin Biblia 1642).

(9) ja se [altaan seinämä] oli kämmenen paxuus ['paksuinen'] (1. Kun. 7:26, Biblia 1642).

(10) ja hänen [temppelin oven] päälisens ja esihuonens olit yhden suurudet ['samansuuruiset'] (Hes. 40:21, Biblia 1642).

Mittaa ilmaisevien ominaisuudennimien lisäksi vanhassa kirjasuomessa on käytetty adjektiivisesti johdosta kohtuus 'kohtalainen, sopiva, siveä' (VKS s.v. kohtuus). Edellisessä Martin maanlain esimerkissä (7) on ilmaus yxi cohtudest corkea mies, ja sama kuuluu Ljungo Tuomaanpojan tekstissä yxi kohtuesta [: kohdus] korkia mies. Adverbi kohtuudesta on muodostettu ominaisuudennimestä, vaikka sti- ja stA-adverbit ovat muuten adjektiivikantaisia, ja se vastaa intensiteettimääritettä 'kohtalaisen (korkea, pitkä)'. 1700-luvun teksteissä on esimerkkejä samassa funktiossa käytetystä genetiivimuodosta kohtuen: cohtuen kylmä. Adjektiiviattribuuttina kohtuus on esimerkiksi ilmauksissa cohtuel menol 'siveästi' (Laurentius Petri 1656) ja kohtuesa wedesä 'sopivassa vedessä' (Lizelius 1776). (VKS s.v. kohtuen, kohtuesta, kohtuus.) Raja mitanilmauksiin näyttää olleen liukuva, joten 
Agricola on voinut laajentaa ominaisuudennimen adjektiivista käyttöä myös yhtyyteen. Vaikka johtosuhteet eivät täysin vastaa mittaa ilmaisevia ekvatiiveja, kohtuudella ja yhtyydellä on ollut jo varhain rinnallaan läheinen (ll)inen-loppuinen adjektiivi, kohtuullinen ja yhteinen. ${ }^{11}$

Vielä läheisempi vastine Agricolan ilmaukselle yhtyyksestä hyvyydestä esiintyy Gananderin sanakirjan fraseologiassa: kolmyxydestä Jumalasta. Gananderin lause-esimerkki perustuu Hemmingin Piae Cantiones -kokoelman esipuheeseen (Hormia 1961, 427), ja sen muotoilussa ominaisuudennimi on selvä attribuutti:

(11) uskons andaa tjetää kolmyxydestä Jumalasta (Ganander 1787 s.v. kolmyhteinen 1. kolmiyhteinen 1. kolmyxynen); vrt. Muinen Piispad / Pappimiehed / Oppined muud Esimiehed / Latinax teid lauluii näitä / Joilla uscons annoid tietä / Herrast luojast Lunastajast / Colmyxydhest cans Jumalast (Hemm1616-A5a, VKK).

Erikoista on se, että Ganander on liittänyt tämän ainoan kolmyksyys-esimerkkinsä hakusanaan kolmyhteinen, kolmiyhteinen ja teorioinut näiden jatkoksi variantin kolmyksynen. Yksyisen kantana on ominaisuudennimi yksyys, eli sanojen johtosuhde on sama kuin ekvatiiviadjektiiveilla (pituinen < pituus). Olen aiemmin arvellut adjektiivia kolmyksyinen virheellisen abstrahoinnin tulokseksi (Mielikäinen 2017,37), mutta kyse on sittenkin semanttisesti loogisesta uudismuodosteesta, adjektiivisesti käytetyn ominaisuudennimen hakusanamuodosta. Kolmyksyinen sopii hyvin Gananderin sanakirjan muuhun aineistoon, sillä hänellä on jo hakusanat useimmista ekvatiiviadjektiiveista, osa jopa ensiesiintyminä: korkuinen, levyinen, pituinen; (ensiesiintymiä) paksuinen, suuruinen, syvyinen. Näiden ohessa on huomattava, että myös kolmiyhteinen on 1700-luvun uudissana (Jussila 1998; VKS).

\section{Lopuksi}

Ominaisuudennimijohdos yhteys on jo varhaisimman kirkollisen kielen sanastoa, ja siitä on tullut joidenkin teologisten tekstien keskeinen termi. Toisaalta se on ollut eräänlainen yleisvariantti, jota on käytetty kaikissa tarvittavissa merkityksissä abstraktista konkreettiseen. Muut $y k s i$-kantaiset rinnakkaisvariantit ovat olleet harvinaisia ja käytöltään rajoittuneempia kuin yhteys. Niillä on kuitenkin voitu eriyttää ja tarkentaa johdosten merkityksiä. Murteiden yhtyys on tunnettu jo 1500-luvulla fraasissa pitää yhtyyttä (Finno), mutta se on sopinut yhteisöä, yhteisöllisyyttä ja yhteisyyttä korostavan merkityksensä vuoksi myös lainopilliseen sanastoon (talonyhtyys talonyhteys 'talousyhtiö'). Agricolan teosten

11 Kohtuus ja kohtuullinen kuuluvat jo Agricolan teksteihin, mutta kohtalainen on tullut kirjasuomeen 1700-luvulla (Jussila 1998). Adjektiivit ovat olleet merkitykseltään läheisiä: kohtuullinen 'kohtalainen, keskinkertainen, sopiva, asiallinen; siveellisesti oikea, oikeudenmukainen, asiaankuuluva'; kohtalainen 'kohtuullinen, sopiva, paras' (VKS). 
kerrallinen yhtyys saattaa olla johdostyypin ensiesiintymä kirjasuomessa. Se erottuu $y$ hteydestä sekä syntaktisesti että semanttisesti, ja se onkin kontekstissaan - suuresta yhtyyksestä hyvyydestä - tulkittavissa adjektiiviattribuutiksi. Vanhassa kirjasuomessa ominaisuudennimien adjektiivinen käyttö on ollut laajaa, sillä ominaisuudennimillä korvattiin 1700-luvulle saakka ekvatiiviadjektiiveja (pituinen) muulloinkin kuin genetiivirakenteissa (jnk pituus). Agricola ei siis ainoastaan omaksunut ja luonut sanastoa uuteen kirjalliseen ja kirkolliseen käyttöön, vaan hän myös hyödynsi sanojen käytössä laajemminkin tuntemiaan suomen kielen ilmaisumahdollisuuksia.

\section{Lähteet ja lyhenteet}

Biblia 1642 = Biblia. Se on: Coco Pyhä Ramattu, Suomexi. Henrich Keyser (Keisari), Tukholma. Näköispainos (Suomalaisen Kirjallisuuden Seura). 1971. WSOY, Porvoo.

Biblia 1776/1991 = Biblia, Se on: Koko Pyhä Raamattu. Esipuhetten, Lukuin sisällyksen, Yhtäpitäväisten Raamatunpaikkain osoituksen ja lisättyin Rekisterein kanssa. Suomen Rauhanyhdistysten Keskusyhdistys, Oulu.

FinNo 1583 [vuosi epävarma] = Jaakko Finnon virsikirja. Näköispainos ensimmäisestä suomalaisesta virsikirjasta sekä uudelleen ladottu laitos alkuperäisestä tekstistä ja sitä täydentävistä käsikirjoituksista. Toimittanut ja jälkisanan laatinut PentTi LempiäInen 1988. SKST 463.

Ganander, Christrrid 1787: Nytt Finskt Lexicon. Alkuperäisestä käsikirjoituksesta ja sen näköispainoksesta toimittanut LiISA NuUTinen 1997. Suomalaisen Kirjallisuuden Seura ja Kotimaisten kielten tutkimuskeskus, Helsinki.

Gummerus, JAакко 1955: Mikael Agricolan Rukouskirja ja sen lähteet. Suomen kirkkohistoriallisen seuran toimituksia XLIV. Aarno Maliniemi ja Aarne Turkka (toim.). Suomen kirkkohistoriallinen seura, Helsinki.

HAKULINEN, LAURI 1979: Suomen kielen rakenne ja kehitys. Neljäs, korjattu ja lisätty painos. Otava, Helsinki.

Holma, Juhani 2008: Sangen ialo Rucous. Schwenckfeldiläisten rukouskirja Mikael Agricolan lähteenä. Yliopistopaino, Helsinki.

Hormia, Osmo 1961. Gananderin sanakirjan lähteet. SKST 271.

IA = Index Agricolaensia I-II. 1980. Kotimaisten kielten tutkimuskeskuksen julkaisuja 11. Kotimaisten kielten tutkimuskeskus, Helsinki.

Jussila, Raimo 1998: Vanhat sanat. Vanhan kirjasuomen ensiesiintymiä. Suomalaisen Kirjallisuuden Seura ja Kotimaisten kielten tutkimuskeskus, Helsinki.

Juusten, Paavali 1575: Se Pyhä Messu Somen kielen ei Pauin Mutta pyhän Euangeliumin ia Christilisen Seuracunnan tauan iälken. Stockholmis 1575. Näköispainos. Toimittanut ja jälkikirjoituksella varustanut MartTi Parvio 1978. Suomalaisen Kirjallisuuden Seura, Helsinki.

KiURU, Silva 1988: Agricolan teonnimijohdosten erikoispiirteitä. Esko Koivusalo (toim.): Mikael Agricolan kieli, 133-179. Tietolipas 112. Suomalaisen Kirjallisuuden Seura, Helsinki.

Koski, Mauno 1979: Nykysuomen assibilaatio. Virittäjä 86, 9-38.

LTS = Ljungo Tuomaanpojan lainsuomennoksen sanasto. Martti Ulkuniemen postuumin käsikirjoituksen mukaan. Antero Niemikorpi, Raimo Jussila, AnNe Kattilakoski, Esko Koivusalo, Heikki Mattila ja ErkKi Rintala (toim.) 2007. SKST 1126.

MAT = Mikael Agricolan teokset I-III. Uudistettu näköispainos. 1987. WSOY, Porvoo.

MielikäInEN, Aila 2017: Kirkollisen kielen numeraalipohjaista sanastoa. Jumalan ykseyttä ja kolmeutta tarkoittavat ilmaukset vanhassa kirjasuomessa ja nykysuomessa. Sananjalka 59, 25-46.

NS = Nykysuomen sanakirja I-III. Lyhentämätön kansanpainos. Kolmas painos. 1970. WSOY, Porvoo. Nummila, Kirsi-Maria - OJUtKangas, Krista 2013: Pyytämättä ja yllätyksenä. Paratagmakonstruk- 
tiot 1500-1800-luvun kirjasuomessa. Sananjalka 55, 73-99.

Parvio, Martti 1978: Paavali Juusten ja hänen messunsa. Liturgianhistoriallinen tutkimus. Suomi 122:3. Suomalaisen Kirjallisuuden Seura, Helsinki.

Pirinen, Kauko 1988: Suomenkielisen liturgisen kirjallisuuden synty. Esko Koivusalo (toim.): Mikael Agricolan kieli, 9-24. Tietolipas 112. Suomalaisen Kirjallisuuden Seura, Helsinki.

Pulkkinen, PaAvo 1966: Asyndeettinen rinnastus suomen kielessä. SKST 281.

Rapola, Martti 1962: Pipliasuomen parataktinen tasapaino. Kielen kuvastimessa. Sana- ja tyylihistoriallisia tutkielmia kirjasuomen aiheista, 169-192. WSOY, Helsinki.

1965 [1933]: Suomen kirjakielen historia pä̈̈piirteittäin I. Vanhan kirjasuomen kirjoitus- ja äänneasun kehitys. Muuttamaton jäljennöspainos. SKST 197.

_— 1966. Suomen kielen ä̈̈nnehistorian luennot. SKST 283.

SKST = Suomalaisen Kirjallisuuden Seuran toimituksia. Suomalaisen Kirjallisuuden Seura, Helsinki.

SMS = Suomen murteiden sanakirja. 2012. Kotimaisten kielten keskuksen verkkojulkaisuja 30. Kotimaisten kielten keskus, Helsinki. Verkkojulkaisu. Saatavilla http://kaino.kotus.fi/sms. Jatkuvasti päivitettävä julkaisu. [Viitattu 15.4.2019.]

SMSA = Suomen murteiden sana-arkisto. Kotimaisten kielten keskus, Helsinki.

VISK = Auli Hakulinen, Maria Vilkuna, Riitta Korhonen, Vesa Koivisto, Tarja Rittta HeiNONEN ja IrJa Alho 2004: Iso suomen kielioppi. Suomalaisen Kirjallisuuden Seura, Helsinki. Verkkoversio. Saatavilla http://scripta.kotus.fi/visk. [Viitattu 17.4.2019.]

$\mathrm{VKK}=$ Vanhan kirjasuomen korpus. Saatavilla http://kaino.kotus.fi/korpus/vks/meta/vks_coll_rdf. xml. [Viitattu 3.5.2019.]

VKS = Vanhan kirjasuomen sanakirja. 2014. Kotimaisten kielten keskuksen verkkojulkaisuja 38. Kotimaisten kielten keskus, Helsinki. Verkkojulkaisu. Saatavilla http://kaino.kotus.fi/vks. Jatkuvasti päivitettävä julkaisu. [Viitattu 15.4.2019.]

\section{Agricolan teosten lyhenteet}

Agr. $1544=$ Rucouskiria. MAT I.

Agr. 1548 = Se Wsi Testamenti. MAT II.

Agr. 1549a = Messu eli Herran Echtolinen. MAT III.

Agr. 1549b = Käsikiria Castesta ia muista Christikunnan Menoista. MAT III.

Agr. 1551a = Weisut ia Ennustoxet. MAT III.

Agr. 1551b = Dauidin Psaltari. MAT III.

\section{Aila MielikëInen: The derivation yhtyys in Mikael Agricola's prayer book Rucouskiria}

There has been a total of five quality noun derivations based on the Finnish numeral $y k s i$ 'one' in old literary Finnish. Only two of these have been preserved in contemporary Finnish: yhteys 'connection, context' and $y k s e y s$ 'unity, oneness'. The earliest and most common is yhteys, which might have been a consciously created derivation. It apparently was required for ecclesiastical terminology in Finnish before Mikael Agricola, and it had become a kind of common variant. Since Agricola, two versions, $y h t y y s$ with a long vowel and the more original ( $y h d y s$ :) yhtye- with a short vowel, have sometimes been used alongside each other, both dialectical variants. $16^{\text {th }}$ and $17^{\text {th }}$ century texts have $y k s y y s$ a few times, 
but only in the compound kolm(i)yksyys ('three' + 'oneness' > 'trinity'). The neologism $y k s e y s$ appeared quite later in $18^{\text {th }}$ century literary Finnish.

The variation between deviation types embodies the differences between dialects and literary Finnish and, above all, the need for $y k s i$-based terminology in theological and juridical specialised Finnish. The choices of variants to some extent have been steered by semantic and contextual justifications. The word yhteys has many different meanings from the abstract (e.g. 'oneness') to the concrete (e.g. 'community'). The noun yhtyys has been a synonym of yhteys, but it has been used in non-theological contexts, especially in the expression adopted from dialects pitää yhtyyttä to be in connection/contact with someone, to be with someone, to have intercourse'. As for $y k s y y s$ and $y k s e y s$, they are complete neologisms created for ecclesiastical Finnish.

The word yhtyys has appeared in Agricola, but only once, as he had consistently used the variant yhteys. The word yhtyys is found in an expression which semantically and syntactically differs from other uses of the word: nijn swresta ychtyxesta hywydhesta (Rucouskiria 1544). In this context, it can only be interpreted as an attribute to the derivation hyvyys ('God's) gift', standard contemporary Finnish 'goodness'), that is, it is equivalent to the $y k s i$-based adjective $y$ hteinen 'shared': in contemporary Finnish it would be niin suuresta yhteisestä hyvyydestä 'about such great shared gifts from God'. Agricola has a few other similarly contextual expressions where hyvyys is described as being yhteinen.

The adjectival use of quality nouns is known in Finnish dialects and other Baltic-Finnish languages to express measurement: polven korkeus '(at the) height of one's knee', kämmenen leveys '(at the) width of one's palm' (the same for paksuus 'thickness', pituus 'length', suuruus 'magnitude' and syvyys 'depth'). This type of expression is also common in old literary Finnish, as equative adjectives derived from quality nouns (korkeus 'height' > korkuinen 'high', leveys 'width' > levyinen 'wide') did not enter literary Finnish until the $18^{\text {th }}$ century. For this reason, quality nouns have syntactically been used in a diverse way, for example in Ljungo, 1601 kynärän pituella kaidickalla ('with a stick at elbow length') and in Antti Lizelius, 1776 cohtuesa vedesä where kohtuus 'reasonableness' qualifies vesi 'water' to mean 'in appropriate water'. The derivation kohtuus has been used as a way to express measurement, and Agricola had applied the same manner of expressing to yhtyys.

Support for the adjectival interpretation of yhtyys comes from the fact that Christfried Ganander had edited a 1787 sentence from Hemminki Maskulainen's poetry to be an example for his dictionary, where Jumala ('God') is qualified by kolmyksyys: kolmyxydestä Jumalasta ('about the triune God'). However, there is no entry or headword for this quality noun, instead Ganander placed the example under the headword, three ways to express the adjective 'triune': kolmyhteinen l. kolmiyhteinen 1. kolmyxynen ('three' + 'one + (i)nen'; l. 'i.e.). There is no other mention of kolm(i)yksyinen in his dictionary nor any information about it anywhere else in old literary Finnish. Thus, it had to have been a headword adjectively theorised and abstractised by Ganander for the word kolmyksyys.

\author{
Aila Mielikäinen \\ aila.mielikainen@jyu.fi
}

